\title{
Ograniczony zakres idiolektu jako skutek niepelnej edukacji na przykładzie osób z wykształceniem podstawowym
}

\author{
Limited language code as a result of an incomplete education on the basis of the research carried \\ out among people with primary education
}

\author{
Iwona LEGUTKO-MARSZALEK \\ Uniwersytet Gdański/ University of Gdansk \\ E-mail: iwona.legutko@ug.edu.pl,
}

\begin{abstract}
In this article there have been presented examples of texts written by people with only primary education. On the basis of linguistic analysis it has been stated that all of them use the same language code. The deliberation was based on the theory of language deeply rooted in a social context. It has been concluded that it is not only primary socialisation in the form of family context which contributes to linguistic development, but first of all, it is a decent education. Nevertheless, biological predisposition, e.g. intelligence can enhance shaping the developed linguistic code, even in children from neglected backgrounds, on the condition that they will be supported by the system of education.
\end{abstract}

Keywords: language code, restricted code, elaborated code

\section{Wstęp}

Język, którym ludzie posługują się na co dzień jest narzędziem umożliwiającym komunikację i wymianę informacji z innymi ludźmi. Nie wszyscy jednak posługują się nim na tym samym poziomie jakościowym. Zależy to zapewne od wielu czynników natury biologicznej, psychicznej czy społecznej, takich jak inteligencja, osobowość czy otoczenie. Ja chciałabym się skupić w tym artykule przede wszystkim na czynnikach środowiskowych, a dokładniej na roli edukacji w procesie kształtowania się rozwiniętego języka (idiolektu). W tym celu przeprowadziłam analizę lingwistyczną tekstów napisanych przez osadzonych w Zakładzie Karnym, którzy uzyskali jedynie wykształcenie podstawowe. Ośmiu skazanych zostało poproszonych o napisanie krótkiego życiorysu/ historii swojego życia. Większość badanych wychowała się w funkcjonalnych rodzinach i nie zaznała deprywacji językowej. Tylko w jednym przypadku można mówić o patologicznej rodzinie, w której badany doświadczył znęcania fizycznego i psychicznego ze strony matki. Badanie to posłużyło do refleksji nad problemem, co właściwie determinuje stopień internalizacji idiolektu. 


\section{Język (idiolekt) rozwinięty vs. język (idiolekt) ograniczony}

B. Bernstein (1971-1975) stworzył teorię języka głęboko zakorzenionego w kontekście społecznym i od niego uzależnionego. Badacz próbował wyjaśnić dobrze znany i udokumentowany związek między szkolnymi osiągnięciami dzieci a ich pochodzeniem społeczno-ekonomicznym za pomocą różnic w użyciu języka oraz jego odmian stosowanych w różnych warstwach społecznych. Wykazał, że istnieje spore prawdopodobieństwo, iż dzieci z domów średniozamożnych będą podlegać socjalizacji, kontroli oraz komunikacji językowej w inny sposób niż dzieci z rodzin robotniczych. Podobne różnice w użyciu języka doprowadzają do wykształcenia wśród dzieci z obu środowisk odmiennych przekonań, aspiracji, nastawień i skłonności do uczenia się, a w końcu także do różnych wyników w nauce.

B. Bernstein w swojej teorii pominął istnienie biologicznych ograniczeń w możliwości przyswajania wiedzy, a wszystkie różnice społeczne odzwierciedlone w języku przypisał takim czynnikom jak podłoże rodzinne i edukacja. Niemniej jednak zwrócił uwagę na różnice w posługiwaniu się językiem u ludzi i wprowadził na stałe do językoznawstwa pojęcia ograniczonego i rozwiniętego kodu językowego (w artykule będę stosowała dla określania tych pojęć nazw ,,język (idiolekt) rozwinięty”, ,język (idiolekt) ograniczony"). Według niego w procesie pierwotnej socjalizacji nabywamy charakterystyczny typ języka, który zdradza naszą przynależność klasową i odróżnia nas od innych klas społecznych.

Według B. Bernsteina klasa robotnicza posługuje się na przykład kodem ograniczonym - najprostszą formą komunikacji. Pod względem strukturalnym charakteryzuje się on używaniem krótkich zdań lub równoważników zdań, często gramatycznie niepoprawnych, ubogim zasobem przymiotników i przysłówków, domyślnym przekazywaniem znaczeń pojęć, tak że zrozumienie przekazu informacji uzależnione jest od znajomości kontekstu wypowiedzi.

Język ograniczony uwrażliwia posługującą się nim jednostkę na „konkret” i powierzchowne związki przyczynowe ograniczając jej możliwości poznawcze, ale ich nie zamykając. Do wyrażania ekspresji często stosuje się mimikę i gesty. W grupie posługującej się ograniczonym językiem często powtarzane są stereotypy czy symbole, przez co język jest łatwo zrozumiały w określonym środowisku, traci jednak wiele wartości komunikacyjnych $\mathrm{w}$ szerszym środowisku. Idiolekt taki w słabym stopniu pobudza psychikę. Wiele zdań wyraża sądy niepodważalne a nadawca informacji często używa zdań rozkazujących.

B. Bernstein w swoich rozważaniach przeciwstawia kodowi ograniczonemu nabyty także w rodzinie kod rozwinięty, zwany również kodem rozbudowanym lub kodem wypracowanym. Idiolekt rozwinięty (w przyjętej tu terminologii) charakteryzuje się zindywidualizowanym podejściem do wyrażania własnych sądów i opinii i nie jest przewidywalny, przez co może być niezrozumiały dla jednostek posługujących się idiolektem ograniczonym. Język rozwinięty to typ języka charakterystyczny dla klasy średniej i wyższej. Jego główne cechy strukturalne to używanie długich, gramatycznie poprawnych zdań, bogate słownictwo, oryginalność konstrukcji językowych, przekazywanie znaczeń pojęć explicite, tak że zrozumienie przekazu informacji jest nieza- 
leżne od znajomości kontekstu. Posługiwanie się tym idiolektem uwrażliwia jednostkę na abstrakcyjne idee i pojęcia, sprzyja poszukiwaniu głębszych związków przyczynowych i pomaga wychodzić poza „konkret”. Osoby posługujące się idiolektem rozwiniętym używają bardziej skomplikowanych narzędzi literackich, stosują logiczną argumentację, zdania są rozbudowane z użyciem spójników a także słów obcego pochodzenia. Niepożądana jest tu żywiołowość emocjonalna, a wypowiedzi są uporządkowane. Język ten charakteryzuje się także umiejętnością relacjonowania stanów uczuciowych. Ze względu na to, że język rozwinięty jest bardziej zorientowany na ekspresję werbalną, bardziej precyzyjny i mniej zależny od bezpośredniego kontekstu, stanowi o wiele bardziej efektywny model komunikacji w sytuacjach, w których nadawca, pragnący przekazać zrozumiały dla adresata komunikat, nie może się odwołać do komunikacji niewerbalnej lub wspólnego dla obu stron doświadczenia.

B. Bernstein (1971) przedstawia w swojej teorii proces ewolucji definicji kodu od określeń w kategoriach wskaźników językowych do określeń rozpatrujących kody według ich zawartości semantycznej. Zawartość ta była w obu przypadkach definiowana jako regulator określonych aktów użycia języka ze szczególnym podkreśleniem systemów semantycznych. Według B. Bernsteina kod językowy pełni funkcję regulatywną, przyswajaną w sposób utajony, umożliwiającą selekcjonowanie i integrowanie istotnych znaczeń, form ich realizacji oraz tworzenie kontekstów. W związku z tym, język reguluje zarówno zasady rozpoznania jak i użycia, co w pewnym sensie nawiązuje do teorii N. Chomskiego (2005) o wrodzonych kompetencjach i nabytym wykonaniu. Przekazywanie i przyswajanie idiolektów odbywa się w interakcjach kulturowo określonych, co wiąże się z pojęciem odmienności sfer problemowych. Nie jest zatem możliwe istnienie językowych i poznawczych kompetencji przyswajanych i podzielanych przez wszystkich, wiąże się to bowiem z określonymi kulturowo regulacjami wszystkich kompetencji, a także dotyczy specyficznych gramatyk semiotycznych dlatego, że występują tu pewne zależności w sferze podziału władzy i zasad kontroli (E. Jaszczurowska 2011).

Język jest symbolicznym przewodnikiem po kulturze danej grupy społecznej, dlatego też kompetencje językowe w języku ojczystym powinny być badane w interakcji z rozmaitymi innymi czynnikami, które ułatwiają lub utrudniają transmisje idei i wzorów zachowań. Stąd też niektóre kręgi posługują się językiem bardziej ograniczonym, inne mniej, co wiąże się także z zakresem doświadczeń osobniczych. Język jest także wyznacznikiem sposobu myślenia i wyrazem interpretacji rzeczywistości obiektywnej. Stąd można wyciągnąć wniosek, że osoba, która jest wychowywana w określonym sposobie interpretowania rzeczywistości obiektywnej, będzie w konsekwencji posługiwała się taką właśnie interpretacją.

Podział na dwa kody (języki) socjolingwistyczne wynika według B. Bernsteina bezpośrednio z warunków i realizacji socjalizacji pierwotnej, czyli ze stosunków miedzy rodzicami i dziećmi, poprzez relacje rówieśnicze aż po związki między pracodawcą a pracownikiem. Wszystkie wymienione tu relacje razem i osobno wpływają na rozwój lub brak rozwoju języków jako nośników pewnych zasad i reguł. Zasady te i reguły składają się na pojęcie kultury w wąskim bądź szerokim znaczeniu. Mówimy tu o kulturze jako zbiorze pewnych reguł postępowania w danym środowisku. W tym 
sensie możemy tu wymienić kulturę społeczności, kulturę przedsiębiorstwa czy subkulturę młodzieżową. W każdej $\mathrm{z}$ nich istnieją pewne zasady, charakterystyczne i ważne dla danej grupy, a podstawowym nośnikiem przekazującym te zasady, normy i kulturę danego środowiska jest język. Zatem zarówno semantyczny, jak i strukturalny czynnik języka jest podporządkowany tym panującym zasadom. Swoją teorią kodów B. Bernstein określił relacje miedzy formami stosunków społecznych a formami mowy. Odnosił się on do różnic w formach porozumiewania się między osobami wywodzącymi się z klasowo odmiennych środowisk. Głównym i najważniejszym przekazem B. Bernsteina zawartym w teorii o kodach językowych jest stwierdzenie, że niewielki procent społeczeństwa otrzymuje dostęp do pokładów intelektualnych z powodu pierwotnego kodu socjalizowania, podczas gdy inni są tego dostępu pozbawieni.

Reasumując B. Bernstein był zdania, że człowiek jest niejako napiętnowany językowo poprzez swoje pochodzenie i rodzinę, w której się urodził. Należy zwrócić przy tym uwagę na fakt, że B. Bernstein skupił się głównie na czynnikach środowiskowych warunkujących rozwój idiolektu. Nie uwzględnił na przykład wrodzonych zdolności czy inteligencji, które determinują rozwój intelektualny niezależnie od warunków socjalnych. Oprócz tego obecny dostęp do edukacji i programy wyrównywania szans umożliwiają kształtowanie umiejętności językowych. Znanych jest wiele przypadków zaniedbanych językowo dzieci z biednych i niewykształconych rodzin, które w procesie edukacji nabywają umiejętności posługiwania się rozwiniętym idiolektem, co umożliwia im dalsze kształcenie się. Niestety te mniej zdolne mogą nigdy nie nadrobić strat i do końca życia będą posługiwać się idiolektem ograniczonym.

B. Bernstein nie rozważył też przypadku, w którym dziecko w procesie pierwotnej socjalizacji może otrzymywać wystarczająco dużo bodźców stymulujących rozwój językowy, jednak w okresie adolescencji zakończy edukację i dominować zacznie środowisko rówieśnicze, które nie będzie pozytywnie wpływało na dalszy rozwój intelektualny, a wręcz będzie go hamować. W takiej sytuacji mimo pozytywnego wpływu pierwotnej socjalizacji człowiek będzie posługiwał się idiolektem ograniczonym. Można więc przypuszczać, że nie tylko środowisko rodzinne, lecz przede wszystkim dostęp do porządnej edukacji będzie miał większy wpływ na rozwój językowy człowieka.

\section{Analiza językowa życiorysów napisanych przez skazanych}

W celu potwierdzenia hipotezy, że brak rzetelnej edukacji determinuje idiolekt danej jednostki, poddałam analizie życiorysy ośmiu mężczyzn skazanych na karę pozbawienia wolności, którzy edukację zakończyli na etapie podstawowym. Poniżej zostały przedstawione wybrane fragmenty tekstów z krótkim opracowaniem lingwistycznym. Przypadki naruszenia norm językowych zostały podkreślone.

\section{(1) Życiorys badanego nr 1 (41 lat)}

„Historia mojego życia, mimo przeżycia 40 lat na tym świcie, jest krótka i raczej 
nieciekawa. Obecnie, jak wiadomo, przebywam w Zakładzie Karnym gdzie odsiaduję karę dożywotniego pozbawienia wolności, bez większej wiary że zachłysnę się jeszcze kiedyś wolnym powietrzem!?... Moje życie to jedno wielkie pasmo niepowodzeń... Ale nie zawsze tak było, dzieciństwo miałem wspaniałe i udane, oczywiście do pewnego momentu, w którym całkowicie się zatraciłem, zachłysnąłem pieniądzem [...] miałem nawet ambitne plany, aż do momentu gdy zapoznałem nowych kumpli, z którymi chciałem podbić świat kradnąc samochody no, było po szkole i mych ambitnych planach. Zamiast wyciągnąć z tego wnioski poszedłem dalej w głupotę i brawurę, która mnie zgubiła i zabiła. Nie dały nic matki łzy i chodzenie po poradniach rodzinnych. Mózg miałem zatróty, a do tego doszły prochy, film się urywa, a przyznam, że nie przebierałem w specyfikach [...] Dramat zaczął się na nowo, wróciłem ponownie do przestępczego procederu, tylko tym razem na ostro straciłem rozeznanie co dobre, a co złe! Pierwszy areszt, wyrok, więzienie [...] Ominę szczegóły bo to po dziś dzień boli. To mój krzyż, który dźwigam na co dzień, nigdy nie pogodziłem się z tym co się wydażyło. Dziś mam inny punkt widzenia od dłuższego czasu żyję w trzeźwości i niech tak zostanie".

Życiorys składa się z wprowadzenia, historii życia i zakończenia. Cały tekst został napisany wielkimi literami, co może w tym przypadku wskazywać na chęć przejrzystego i starannego przekazu. Oprócz chronologicznie przedstawionych faktów mamy również dygresje i refleksje dotyczące życia badanego. Konstrukcje zdaniowe są poprawne gramatycznie i wielokrotnie złożone, jednak brakuje przemyślanej, podzielonej znakami interpunkcyjnymi, koherentnej struktury. Gdzieniegdzie można zauważyć osobliwy szyk zdania, np. dopełnienie na pierwszym miejscu oraz pisanie o sobie w trzeciej osobie, np.: Ale mimo ich troski nie poradzili sobie z tzw. buntem nastolatka który zamiast rodzine, pokochat ponad wszystko ulicę i jej zdradliwe zasady (...).

Słownictwo jest w miarę zróżnicowane i bogate w humorystyczne określenia pod swoim adresem: dostałem małpiego rozumu, byłem odporny na wiedze, miałem ambitne plany, podstawówkę ukończyłem tylko dzięki niej (matce) i jej determinacji, po opuszczeniu „Monaru” wytrzymałem jeden dzień, rok trzeźwości poszedt $w$ diably. Badany stosuje rozwiniętą interpunkcję, włącznie ze znakami rozkazującymi i pytającymi oraz wielokropkiem, chociaż nie zawsze stosuje ją właściwie. W tekście występuje również kilka błędów ortograficznych. W przypadku tego badanego widać, że mimo niewątpliwego potencjału intelektualnego i pozytywnego oddziaływania środowiska rodzinnego nie zinternalizował on języka na poziomie rozwiniętym.

(2) Życiorys badanego nr 2 (35 lat)

„Pobyt w izolacji od rodziny, dzieci i najbliższych, który tylko nas uzwierzęca. 23 godziny na dobę w klatce, bez żadnych perspektyw na przyszłość. Program resocjalizacyjny, który skupia się na zabieraniu wszelkich udogodnień [...] żadnych szans na szypszy powrut na wolność [...] człowiek popełnia jakiś życiowy błąd i zostaje z tym sam jak palec. Nikt nie prubuje mu w żaden sposub pomuc."” 
Struktura tekstu, który właściwie nie jest życiorysem skazanego, tylko skargą na system penitencjarny, jest chaotyczna i nieprzemyślana. W tekście dominują zdania niepełne lub równoważniki zdań. Słownictwo jest ubogie, zależne od kontekstu i ogranicza się głównie do konkretnych pojęć. Cały tekst napisany został wielkimi literami, co w przypadku tego badanego może sugerować niewykształconą umiejętność posługiwania się literami pisanymi sądząc po niskiej kompetencji językowej. Autor tekstu popełnia podstawowe błędy dotyczące zasad pisowni, np. ukrucaniu, szypszy powrut itp. i nie stosuje interpunkcji w formie przecinków. Pisanie o sobie w trzeciej osobie jest próbą dystansowania się od swoich czynów.

(3) Życiorys badanego nr 3 (39 lat)

„Moje dzieciństwo było dość dobre do 14 roku życia dobrze się uczyłem nie wagarowałem dopiero po ukończeniu lat 14 zaczeło się wagarowanie ucieczki z domu kradzieże napady alkochol starsi koledzy recydywiści próbowanie nowych żeczy takich jak narkotyki i.t.p. zaczoł się ten chandel narkotykami jak tego było po czasie zaczynałem kraść samochody na zlecenia okradałem domy sklepy churtownie przezco weszłem w konflikt z prawem i tak do dzisiaj włuczę się po kryminałach [...] w domu mogę że relacje rodzinne wychowawcze były dobre alkocholizmu w domu nie było ojciec od czasu do czasu spożywał tylko alkochol co jest dla ludzi z umiarem jeśli raz w tygodniu sobie wypił to uważam że to niebył alkocholizm [...] odbywam karę dożywotniego pozbawienia wolności od 16 lat przebywam z Z.K. do przed terminowego zwolnienia zostało mi jeszcze 9 lat $[\ldots] "$.

Z powyższego fragmentu można wywnioskować, że edukacja ma większy wpływ na rozwój idiolektu niż pierwotna socjalizacja. Badany pozostał na etapie idiolektu ograniczonego, mimo odpowiedniej stymulacji językowej we wczesnym wieku. Tekst charakteryzuje się stosowaniem najprostszych konstrukcji zdaniowych, jest chaotyczny i napisany jednym ciągiem, nie uwzględniając znaków interpunkcyjnych, co utrudnia w dużym stopniu czytanie. Oprócz tego szyk zdania zaburza czasami zrozumienie właściwego znaczenia wypowiedzi.

Autor tekstu stosuje wiele powtórzeń, co świadczy o niewielkim zasobie słownictwa, które ogranicza się do konkretnych pojęć i jest zależne od kontekstu sytuacyjnego. Najbardziej znamienna jest nieznajomość podstawowych zasad pisowni, widoczna między innymi w błędach ortograficznych typu sytułacji, procętach, przed terminowe, przezco, puttora, wogóle, żeczy, alkoholizm itp. co sprawia, że tekst trzeba w niektórych miejscach dosłownie rozszyfrowywać.

(4) Życiorys badanego nr 4 (32 lata)

„Urodziłem się w 1987r. w Szczecinie, jako jedynak z wadą roszczepu podniebienia. Od kiedy zaczełem uświadamiać sobie że żyję, wiedziałem że jestem trochę innym dzieckiem z wyglądu. Rodzice, których miałem do 8 i 12 roku życia, bardzo poświęcali mi uwagi ze względu na schorzenie które mi się trafiło. Również 
u moich dziadków byłem wybranym wnuczkiem i mogłem dużo więcej niż pozostali. Lecz moi rodzice mają czarną stronę swojego życia. Byli narkomanami pierwszymi heroinistami w PRL-owskiej Polsce. Którzy brali dożylnie tzw. kompot. Od kiedy pamiętam mam przed oczami szczykawki w szufladzie z igłami. Tak samo produkcja tego narkotyku trwale utkwiła mi się w pamięci. Smród gotowania w kuchni maku przy zamkniętych oknach, tak by nikt nie wyczuł ze wnatrz z sąsiadów. Przeważnie musiałem być w tedy w domu by się nie kręcić pod byle smarkatym pretekstem [...] Moje problemy emocjonalne zaczęły się gdy zaczelem palić w 5 klasie marichuanę. Chciałem zaimponować starszym kolegom i się udało. Byłem w takich grupach zaprzyjaźniony do których zwykli śmiertelnicy z ławki szkolnej mogli pozazdrościć [...] Oprócz picia i robieniu sobie problemów z prawem, nie interesowało mnie nic. Nie było nikogo kto by mi przetłumaczył wtedy do głowy że robie źle i zaprowadzi mnie to do więzienia. Aż w 2008r. trafiłem do zakładu i chyba to mnie trochę otrząsnęło i pozbierało, jeśli chodzi o dbanie o swój wizerunek [...] Po 3 latach od wyjścia znów weszłem w konflikt z prawem na tyle, że w 2013r. trafiłem na sankcje za rozbój oraz za wcześniejsze kradzieże sklepowe. Miało mi się razem uzbierać pajda wyroku [...] A za to wdałem się w kolejną bójkę z sąsiadem murzynem z której wyszło rozbój na tle rasowym zostałem skazany na 5 lat".

Obszerny tekst (4 strony A4) został napisany wielkimi literami, ale biorąc pod uwagę poziom i starania chronologicznego odtworzenia swojej historii życia, można przypuszczać, że badanemu chodziło tu raczej o przejrzystość. Badany potrafi tworzyć zdania zarówno proste, jak i złożone, przy czym nie zawsze są one poprawne gramatycznie. Znaki interpunkcyjne stawia w niewłaściwych miejscach lub je całkowicie pomija. Można zauważyć niekonsekwencję dotyczącą stosowaniu czasu, niewłaściwą deklinację, np. dopełniacz zamiast biernika, nieprzestrzeganie rekcji czasownika i odmiany z uwzględnieniem zgodności podmiotu i orzeczenia co do rodzaju, osoby i liczby.

W odniesieniu do słownictwa mamy tutaj do czynienia $\mathrm{z}$ utrwalonymi wyrażeniami typu: notoryczne palenie trawki, budować relacje, doznania życiowe oraz neologizmami, np. heroiniści, przećpała. W niektórych miejscach można nawet zaobserwować wzniosły czy nawet poetycki ton, np. w sformułowaniach typu otworzenie się na kartke papieru, reszta mojego rodzica, czy w opisie śmierci matki: Mój ostatni widok matki leżacej bezwładnie mrugajaca oczami patrzaca na mnie. To byt pożegnalny nasz ostatni raz. Autor tekstu wykazał się również sarkazmem w odniesieniu do swojego wujka: Mój kochany wujek zaczol wyjeżdzać do pracy za granice, więc miałem trochę więcej spokoju psychicznego. Mamy również przypadki pytań retorycznych: od czterech lat mieszkała z nami dziewczyna wujka która zaszła w ciąze i chyba to była przyczyna, lecz dlaczego w taki brutalny sposób. Mimo satysfakcjonującego ogólnego poziomu tekstu można znaleźć liczne błędy dotyczące podstawowych zasad pisowni, np. rozłonki, ciagnoł, drógie, zaczoł, wruciła, naugowego palenia podjetem, $w$ między czasie, testą. W tym przypadku badany również doświadczył pozytywnej socjalizacji pierwotnej, a jednak nie zinternalizował idiolektu na poziomie rozwiniętym. 
(5) Życiorys badanego $\mathrm{nr} 5$ (36 lat)

„Moje dzieciństwo nie było takie, jak u wielu moich kolegów, czy innych rówieśników, których znałem. W domu bywało różnie, tj. zła sytuacja finansowa, częste kłótnie ze strony taty, dość dużo krzyku, raczej mało ciepła rodzinnego, brakowało wsparcia i wielu różnych uczuć, które bywały sporadycznie albo ja ich nie potrafiłem dostrzec, a które pozwoliłyby na to, że chce się wracać do domu [...] W domu pojawiał się alkohol i często z tego powodu pojawiały się ostre kłótnie, czy raczej krzyki (choć to i tak za lekko ubrałem w słowa), których miało się dość i chciało się wyjść z domu i nigdy do niego nie powracać [...] Kiedy z kolegami spędzałem czas do bardzo późna to, zaczęliśmy rozmyślać nad tym z kạd brać pieniądze, których nam mocno brakowało na wiele różnych rzeczy. Tak się właśnie rodziły bardzo głupie pomysły, które czasem dawały pieniądze ale i przynosiły też różne problemy prawne. Bywało tak, że wiele z pomysłów trzeba było realizować w czasie lekcji i było z tego powodu bardzo dużo opuszczonych dni i od groma różnych zaległości z tym związanych [...] Tam (Ośr. Szk. Wych.) poznałem nowych „fajnych” kolegów i zaczęliśmy realizować pomysły, które miały nas doprowadzić do bogactwa, a zaprowadziły do Z.K. [...] Gdy siedziałem moje myślenie się trochę zmieniło i postanowiłem żyć normalnie tj. iść uczciwą drogą. No ale tak się nie dało bo nasza wspaniała Policja sprawiła bez żadnych świadków, że złamałem prawo $\mathrm{w}$ postaci naruszenia nietykalności, znieważenia i groźby karalne pod adresem Policji [...] Ale co ten recydywista tutaj wypisuje, pewnie był winny lub zawinił bo Policja taka nie jest. Ś.P. Igor Stachowiak sam się prosił by go na komendzie w toalecie razili kilka razy paralizatorem, aż zmarł. Powracając do mojej historii życia, to ona cały czas się tworzy. Teraz mam już odsiedziane w swoim życiu ponad 10 lat i w przyszłym roku mnie wypuszczą. Każdego dnia rozmyślam jak zarobić duże pieniądze i przybliżyć się do swoich marzeń, które są do osiągnięcia [...] Życie nie takie, jakie by się chciało mieć ale jest moje i nadal trwa. Teraz mam ogromną determinację do tego by życie przeżyć możliwie najlepiej jak się da [...] Może i trochę chaotycznie i, w niektórych fragmętach nie wchodząc w szczegóły, ale z grubsza tak to wyglądało [...] Chciałbym wierzyć, że o coś takiego chodziło i jakoś dałem radę. Czasu na to zbyt wiele nie miałem i może po części tak dlatego to napisałem".

Mimo podstawowego wykształcenia badany posługuje się sprawnie językiem pisanym tworząc zdania złożone i poprawne gramatycznie nie tylko w trybie oznajmującym, ale także przypuszczającym i pytającym. Słownictwo jest w porównaniu do innych badanych zróżnicowane i bogate w przymiotniki, przysłówki, imiesłowy, miejscami nawet wyszukane, np. determinacja, zakłamanie, kumulacja, zastraszanie, znieważenie, fatsz, nastrój, potęgować, stwarzać pozory, skutkować i zaskakujące humorem i refleksyjnością, np.: ,ziś jestem zupetnie inna osoba i mimo miejsca mam $w$ środku siebie wielki uśmiech. Może to przez te swoje wybory i decyzje nie zawsze dobre jestem kim jeszcze z 2-3 lata temu nie byłem? (inne przykłady w cytowanym fragmencie). 
Autor życiorysu jasno formułuje myśli, trafnie wyrażając związki przyczynowo skutkowe, co jest widoczne w powyższym fragmencie. Czasami stosuje bezosobową formę czasownika, np. nie miało się żadnego pokoju, w którym można by się było zamknać $i$ w jakiś sposób wyciszyć, wiele z pomystów trzeba było realizować $w$ czasie lekcji $i$ było z tego powodu bardzo dużo opuszczonych dni i od groma różnych zaległości z tym zwiąanych, czasem odnosito się wrażenie, że większość mieszkańców domu była jakby zastraszona czy zlękniona, aby nadać bardziej obiektywny charakter swojej wypowiedzi lub pisze o sobie w trzeciej, np.: co ten recydywista wypisuje. Należy również zwrócić uwagę na świadome użycie takich figur stylistycznych jak dygresja, ironia czy metafora.

W życiorysie znajdują się również błędy, np. z tąd czy fragmęt, co świadczy o brakach w edukacji. Badany ten nie doświadczył pozytywnej stymulacji językowej we wczesnym dzieciństwie, a mimo to wykazał się najwyższą kompetencją językową ze wszystkich badanych. Chociaż nie mamy tu jeszcze do czynienia z rozwiniętym idiolektem, to z pewnością osoba ta posiada duży potencjał intelektualny. Mimo, że badany nie skończył nawet szkoły podstawowej, potrafi bez problemu wyrażać swoje myśli w sposób logiczny i stylistycznie satysfakcjonujący, co pozwala wnioskować, że w innych warunkach zinternalizowałby idiolekt na poziomie rozwiniętym. Powyższy przykład przeczy teorii B. Bernsteina, a potwierdza moją hipotezę, że system edukacji jest w stanie wyrównać poziom językowy dzieci ze zubożałych pod względem stymulacji rozwojowej środowisk do poziomu dzieci z tzw. „dobrych domów” pod warunkiem, że są to dzieci inteligentne.

(6) Życiorys badanego nr 6 (35 lat)

,[...] gdy miałem 7 lub 8 lat wruciliśmy w strony Matki po nie udanym zwiassku zamieszkaliśmy u Bapci lecz nie trwało to długo oczywiście przyczyniła sie do tego Matka która prowadziła wesołe życie przy czym były awantury dla tego też Bapcia nie chciała Matki usiębję zamieszkaliśmy u sąsiada który prowadził podobny tryp życia jak matka, alkohol i.t.p. między czasie Gmina przyznała Matce mieszkanie 1 pokui i kuchnia i dopiero wtedy zaczeło się piekło gdy zamieszkaliśmy sami głodzenie wyzwiska pruby przypalania jak i niszczenia tego co było wemnie, mianowicie mojch zainteresowań czyli taniec był czas kiedy rozwiałem się w tym kierunku czyli bregoleś lecz z każdym dniem jak i rokiem Matka gasiła wemnie cheć do tego co dobre tym że byłem bekartem [...] nie potrafiłem sobie poradzić zemociami, pograzałem sie coraz bardziej [...] spędziłem 10 lat ogułem w Zakładzie karnym, chodziłem do Pani Psycholog prowadziłem rozmowy różnego kroiu, które do dziś bolą które nie pozwalają mi na to by uwieżyć wsiębję poniewasz nie czuję sie godny by żyć przez to czego dopuściłem się w życiu swym i tak jest nadal po opuszczeniu zk chciałem na nowo ułożyć sobie życie tylko popełniłem błot wruciłem do rodzinnego domu gdzie podczas rozmuw przeprowadzonych z Panią Psycholog stwierdziła że nię mogę wrucić do Matki bo wruce do Z.K. i tak się stało nie chciałem by tak się stało lecz po ognisku pod wpływem alkoholu dopuściłem się czynu który jest tak chaniebny nie potrafie rozmawiać onim otwarcie [...]". 
Życiorys został chronologicznie przedstawiony, jednak strukturę tekstu zaburzył całkowity brak interpunkcji. Konstrukcje zdaniowe są bardzo proste, bazujące głównie na krótkich zdaniach pojedynczych. Słownictwo jest ubogie w przymiotniki i przysłówki, dlatego w tekście widoczne są liczne powtórzenia. Czytanie ze zrozumieniem utrudniają błędy dotyczące podstawowych zasad pisowni, jak na przykład utrata dźwięczności głosek w mowie a nie piśmie, np. otpowiędzj, sposup, równiesz, pisownia z $q$ i ę np.: znecanie, wstret, sie, siębję, nię oraz zasada pisowni $i / j$, np. wjele, ciogle, przez co dochodzi do zmiany znaczenia, np. zamiast rozwijałem wychodzi rozwiatem. Pozostałe przykłady dotyczące nieprzestrzegania zasad ortografii to $d o$ puki, żeczy, wieżyć, buikj, asz, przychamować, powrucitem, chaniebny, błot, rozmuw, filmuw, stość, przydzi.

Dodatkowo można zauważyć nieznajomość reguł gramatycznych, np. między innymi zasady pisowni wyrazów razem lub oddzielnie, np. dla tego, czego kolwiek, ty nie robie, na gadać, wemnie, otym. Autor w wielu miejscach nieprawidłowo odmienia przez przypadki i w zasadzie pisze tak jak mówi. Jest to jedyny przypadek, w którym patologiczne środowisko mogło mieć duży wpływ na zahamowanie rozwoju językowego. Nie wiadomo jednak, jaki poziom językowy prezentowałby badany, gdyby doświadczył porządnego wsparcia ze strony systemu szkolnego.

(7) Życiorys badanego nr 7 (36 lat)

,[...] Niedziała tu żaden proces resocjalizacji a wręcz pogłębia się moja demoralizacja. Jestem otoczony ludźmi z marginesu społecznego, przy których w żaden sposób się nierozwijam intelektualnie a wręcz odnoszę wrażenie że cofam się w rozwoju. $\underline{Z}$ miesiąca na miesiąc jestem coraz bardziej nerwowy i mój stan psychiczny ulega pogorszeniu. Przepisy regulaminu są krzywdzące ponieważ izolują mnie z moją rodziną przez co cierpię nie tylko ja [...] Do tego jesteśmy izolowani 23 godz. w celi i tylko jedna godz. spaceru, to jak tu nie zwariować?! Warunkowe zwolnienia to też jakiś pusty przepis w Kodeksie Karnym Wykonawczym ponieważ niedają prawie nikomu tych zwolnień a jak już to marne ochłapy [...]”.

Powyższy fragment to skarga na system penitencjarny składająca się z konkretnych argumentów przedstawionych w szyderczym tonie, np. 7 min. telefonu to jakaś kpina!, $6 \mathrm{~kg}$ paczka żywnościowa? Wolne żarty! Struktura tekstu jest zwarta i koherentna, a zdania złożone, ale pozbawione interpunkcji, przez co są czasami nieczytelne. W tekście występuje gdzieniegdzie wyszukane słownictwo, np. system penitencjarny, demoralizacja, utrzymywać więzi, opieszale. Jeśli chodzi o gramatykę, to badany wyraża zmianę stanu za pomocą czasownika statycznego, stosuje nieprawidłową rekcję czasownika i odmianę przez przypadki, np. nie sponsoruje to skarb państwa! oraz nie zna zasady pisowni nie z czasownikami. Błędy świadczą o dużych brakach ze strony systemu edukacji, natomiast wyżej wymienione słownictwo czy refleksyjne sformułowania, np. cofam się w rozwoju, przepisy regulaminu sa krzywdzace sugerują potencjał intelektualny. Przy odpowiednim wsparciu ten badany mógłby osiągnąć wyższy poziom kompetencji językowej. 
(8) Życiorys badanego nr 8 (64 lata)

„,...] Do 16-tego roku życia mieszkałem w dzielnicy „Zdroje”, następnie wraz z rodziną przeprowadziliśmy się do dzielnicy „Pomorzany”, gdzie zaczeła się moja niechlubna kariera. Rok po przeprowadzce wylądowałem w Zakł. Poprawczym, po wyjściu w 1974, po roku na wolności, pierwszy raz wylądowałem w więzieniu. Po wyjściu w 1981r. wziełem ślub będąc na wolności. Z tego związku mam syna - wspaniały chłopak, od ponad 10-ciu lat wraz z żoną i cureczką mieszka poza granicami kraju. Nadmieniam, że jest to jedyne moje dziecko. W połowi 80-tych lat kiedy ponownie siedziałem, żona wzieła rozwód i wyprowadziła się [...] Ja jak zwykle oczywiście siedziałem, i tak z małymi przerwami siedzę do dzisiaj".

Struktura tekstu przypomina sprawozdanie. Badany relacjonuje w chronologiczny sposób, kiedy trafiał do zakładu karnego i z niego wychodził nie wgłębiając się w jakiekolwiek bliższe informacje dotyczące życia. W tekście dominują przeważnie krótkie zdania, ale poza nielicznymi błędami napisany jest starannie i gramatycznie poprawnie. Słownictwo jest ubogie w przymiotniki i przysłówki, mamy wiele powtórzeń, np. wyladować, wziać i wyjść. Z powyższej historii życia można wywnioskować, że badany mógłby zinternalizować idiolekt na poziomie rozwiniętym, gdyby nie zakończył zbyt wcześnie edukacji.

\section{Wnioski}

Na podstawie przytoczonych fragmentów życiorysów można stwierdzić, że wszystkie prace są w mniejszym lub większym stopniu przykładem stosowania przez autorów ograniczonego idiolektu. Badani nie wykazali się umiejętnością pisania dłuższego, rozbudowanego i koherentnego tekstu. Czytając życiorysy odnosi się wrażenie, że badani przelewali bezpośrednio na papier dosłownie wszystko, co im przyszło do głowy. Dlatego powyższe teksty charakteryzuje w większości chaotyczna struktura, zaburzona chronologia historii życia oraz częste dygresje.

Konstrukcje zdaniowe nie są złożone i oryginalne. Dominują krótkie zdania lub równoważniki zdań, często niepoprawne gramatycznie. Tylko w dwóch przypadkach badani potrafili poprawnie budować zdania podrzędne, ale nie potrafili zastosować w odpowiednich miejscach interpunkcji. Mamy bardzo dużo przykładów nieznajomości podstawowych zasad pisowni w języku ojczystym. Charakterystyczny jest również ubogi zasób słownictwa, czego skutkiem jest stosowanie wielu powtórzeń zamiast synonimów.

W żadnej pracy nie zastosowano przydawki rozwiniętej czy innych bardziej złożonych struktur językowych. Badani relacjonują kolejne epizody swojego życia nie poszukując głębszych związków przyczynowo skutkowych. Nie stosują skomplikowanych narzędzi literackich i logicznej argumentacji. W swoich wypowiedziach formułują sądy niepodważalne, których czasami nie rozumieją, np. że relacja rodzica $\mathrm{z}$ dzieckiem zależy od obecności rodzica w jego życiu. Wypowiedzi formułowane są w sposób ekspresyjny, co może być spowodowane sytuacją życiową i pobytem w więzieniu. 
W odniesieniu do teorii B. Bernsteina należy stwierdzić, że nie tyle pierwotna socjalizacja, co przede wszystkim edukacja i kontynuacja pielęgnowania nabytego języka jest istotna, aby zinternalizować idiolekt na poziomie rozwiniętym. Dowodem tego jest badany nr 5, który mimo dysfunkcyjnego środowiska rodzinnego osiągnął wyższy poziom kompetencji językowej niż badani, który wychowywali się w sprzyjających rozwojowi języka warunkach. $Z$ kolei najgorszy pod względem językowym życiorys napisał badany nr 3, który miał wspaniałe dzieciństwo, był otoczony opieką i troską, a zatem doświadczył pozytywnej socjalizacji pierwotnej. Reasumując wszyscy badani prezentują ograniczony idiolekt, co jest bez wątpienia wynikiem uwarunkowań środowiskowych, w tym braku solidnej edukacji. Przedstawione przykłady potwierdzają teorię Bernsteina, że środowisko jest głównym czynnikiem kształtującym język. Niemniej jednak należy również uwzględnić predyspozycje biologiczne, np. inteligencję, co wyraźnie pokazały przytoczone przeze mnie przykłady życiorysów.

\section{Bibliografia}

Bernstein, B. (1971-75), Class, Codes and Control (tom 1, 2, 3). London.

Chomsky, N. (2005), O naturze i języku. Warszawa.

Jaszczurowska, E. (2011), Kody socjolingwistyczne i edukacyjne. Bielsko-Biała. 